\title{
How to stop the space station
}

Protests against the proposed space station Freedom continue, but the US Congress is likely to approve the project. The time has come for counter-arguments of a different kind.

LAST week, in an extraordinary show of unity, the presidents of 14 US scientific societies, representing both the physical and biological sciences, called on the US Senate to kill the controversial space station "Freedom" which, within recent weeks, has been voted down and then up again by the House of Representatives. The gist of the presidents' arguments was this: Freedom, at a conservatively estimated cost of $\$ 30,000$ million, cannot be justified as a valid scientific experiment. Worse, if spent, the $\$ 30,000$ million would be lost to "real" science even in cognate fields such as satellite communications and remote sensing research.

Last week's gang of 14 - representing the American Physical Society, the Geophysical Union and the Society of Zoologists, among others - is not, of course, the first to argue against the space station on the grounds that it has no substantial scientific purpose. But the gang's argument will not be listened to. For all practical purposes, the pro-Freedom lobby concedes that the space station cannot be justified as a remote, even a weightless, science laboratory. White House science adviser D. Allan Bromley is among those who say that science is not all; instead, he says the argument is between "investments in the future and current consumption".

Bromley's White House colleague, budget director Richard Darman, is even more lyrical: Freedom may not be the best possible route to space exploration, but where we would be now if Columbus had been forbidden to set sail or if the pioneers who settled the American West had stayed East waiting for the development of aircraft to convey them to California in greater comfort than the horse-drawn wagons in which they travelled? And there are less high-sounding arguments to be heard in favour of Freedom. US relations with Japan and Europe would suffer deservedly if the United States backed out now when those countries have contributed millions of dollars (see Nature 351, 428; 6 June 1991) — a worthy consideration that has not always carried weight in Washington. And then, as if Freedom were a hangover from the days of the Public Works Administration of the 1930s depression, people are busily calculating how many thousands will lose their jobs, or at least will not enjoy jobs that do not yet exist, if Freedom is not assembled.

At the heart of the issue is the fascination of the United States with exploration, or at least with adventure. The Apollo programme is still affectionately alive in many people's memories (and often wins a mention in the community's defence of the research enterprise). However rational, the weakness of the argument that Freedom serves no useful scientific purpose is that it leads to a self-serving conclusion. It is as if the professional community is saying in killjoy fashion that, if the space station takes money from research, then the community is against it - whatever pleasure it might give the United States or even the world at large.

Earlier this week, the first Senate committee vote seemed to endorse the position taken by the House of Representatives; it seems likely that the full Senate will follow. What the gang of fourteen should learn from these developments, however unwelcome, is that the only effective counter to the arguments for Freedom is in coinage of the same kind. Of course, there are economic arguments, but they are not clinching; spread over ten years, Freedom will cost less than 2 per cent of the budget deficit if that persists at its present level.

So perhaps it is time to concentrate on guessing at and then telling what kind of an adventure Freedom will be. Mallory's view that people climb Everest "because it is there" is at least justified by the height of the mountain. And the Moon was "there" for Neil Armstrong, who reached its surface with aplomb. But what is to be made of an adventure to an orbit about the Earth in which people will simply go round and round in near-circles, doing as little as they can the while to disturb the solemn people busy on microgravity experiments and themselves at the beck and call of the logistics experts who will tell them what to eat, and when, and when the time has arrived to pack up and go home. There may be a little serious science to be done, but it will not be cutting-edge stuff.

\section{Bankrupt systems}

The collapse of a British-based bank raises questions about the new world order as well as bankers' probity.

THE circumstances leading to the enforced shutdown last week of the Bank of Credit and Commerce International (BCCI) are not just a scandal, but a sign that we are a long way from what President George Bush has been calling the new world order. For what the collapse of this bank 